\title{
Food hygiene knowledge and awareness among undergraduate maritime students
}

\author{
Taha Talip Türkistanlı, Coşkan Sevgili
}

Dokuz Eylül University Maritime Faculty, Tınaztepe Campus, İzmir, Turkey

\begin{abstract}
Background: Reducing the crew size of the galley department on merchant vessels causes heavy workload for the remaining food handlers on board. This situation in return, could trigger risky behaviours and create an unsanitary environment which can facilitate the spread of various gastrointestinal disorders on ships. In such cases, ensuring and supervising food hygiene and food safety on board is up to maritime captains and officers. In addition to that, each crew member on board should maintain a general awareness of food hygiene to prevent any outbreaks. However, these personnel's knowledge and awareness to prevent such risky behaviours and cases are questionable. In this context, this study aims to examine food hygiene knowledge as well as awareness among maritime students. A survey has been conducted to discover the risky behaviours seen on merchant vessels regarding food hygiene. Specified training needs to achieve food safety culture on merchant vessels are discussed.

Materials and methods: The study was conducted by proposing an anonymous questionnaire to undergraduate students of maritime faculties in Turkey. The questionnaire form was adapted from the previous works of Grappasonni et al., Walker et al. and Alpuguz et al. This questionnaire examines the basic attitudes towards food hygiene and risky behaviours among seafarers. Convenience sampling technique was adopted, and 251 Turkish participants have joined the study.

Results: Foodborne disease knowledge among maritime students was determined to be low especially for disease recognition. They have failed to identify characteristics and symptoms of food borne diseases. There were also serious misconceptions of which behaviours are considered risky regarding food hygiene. A knowledge gap was observed in cross-contamination, food temperature control, and food storage condition subjects. Some of these, such as high-risk foods and adequate storage of foods should be common knowledge for all personnel on board. It is also revealed that food hygiene awareness of many maritime students was limited to environmental hygiene and food handlers' hygiene.

Conclusions: Food hygiene appears to be an underrated problem on board, yet it is one of the major health problems in the maritime industry threatening the seafarers. Promoting food safety culture and food hygiene knowledge in maritime students could be a key factor to tackle this problem. Development of standardised health and disease training for seafarers should be considered.
\end{abstract}

(Int Marit Health 2018; 69, 4: 270-277)

Key words: food hygiene, risky behaviours, shipboard food handling, foodborne diseases

\section{INTRODUCTION}

Working conditions and life on board ships differ a lot from the working conditions of other professions. Individuals working on vessels have to spend their time on board. This means activities such as; sleeping, resting, socialising and eating are done on board. In a way, a ship's crew form a small community responsible for each other in many various factors such as hygiene conditions in common areas and cabins and providing positive conditions for the overall well-being of others. However, preparing and cooking three meals a day besides cleaning the ship's kitchen and storages is usually entrusted to a single person. Therefore, 
food professionals on board ships play an important role in protecting people from foodborne diseases [1].

Manning merchant vessels with a dedicated galley crew is a widely accepted practice in the maritime industry for some time. Cleaning and maintaining the quarters, preparing and serving food are in the responsibility of this department. As a rule of thumb, a galley crew in merchant vessels includes a chief cook and stewards. Some shipowners and managers might also hire dedicated cleaning personnel or second cook while other owners and managers might discard all personnel except the chief cook. These conditions are circumstantial and may differ from vessel to vessel. However, disregarding most of the galley crew to reduce costs, results with a single food handler who is also responsible for the cleaning and maintaining of stores and quarters, in addition to cooking and serving. This heavy workload could trigger risky behaviours and a change in food safety culture or awareness may create unhealthy conditions. This situation combined with confined spaces and limited fresh food supply on board poses a potential threat to the general well-being of seafarers [2, 3].

It can be argued that each person on board should be aware of the nature and condition of their food before consuming any. However, it might not always be practical to inspect every step of food preparation. Therefore, the master or the chief officer usually acts as the supervisor of the galley department, depending on the company policy and job descriptions. It is in their responsibility to inspect and keep overall hygiene conditions in check. Yet, without adequate knowledge and awareness, it is impossible for a ship's crew to take precautions for risky behaviours. In the end, these risky behaviours result in gastrointestinal disorders and disease outbreaks [4]. Underestimating the outbreaks on board of cargo ships may create fatal outcomes. Inspections revealed that deficiencies in food and cookery hygiene are indeed relevant problems for ships [3]. This situation is especially more concerning when we consider the fact that a ship's crew is isolated and spending long times at sea, sometimes in remote regions of the world and without adequate medical care [5].

The literature on food hygiene is rather extensive. A research conducted by Grappasonni et al. [4] investigates the food hygiene knowledge of seafarers and ashore personnel for a certain maritime firm. Another study conducted by Mouchtouri et al. [6, 7] examines the food hygiene and safety on passenger ships. There are also several studies conducted on students from various domains [8-14] and some of them focus on more specific groups like health and tourism undergraduate students [15-19]. However, studies on food hygiene and food safety culture in the maritime domain are limited even though food hygiene is an important factor for the health of the crew.
This paper discusses knowledge, awareness and risky behaviours related to food hygiene seen on merchant vessels. In this context, we evaluate different grade maritime students' knowledge and asses their awareness regarding the food safety conditions on board. We also survey the possible risky behaviours of young seafarers related to food hygiene. This way we aim to identify suitable ways to promote food safety on board ships.

\section{MATERIALS AND METHODS}

A survey was conducted on undergraduate students of maritime faculties located in Turkey to make an assessment on food hygiene and food safety culture. The questionnaire used in this survey was adapted from the works of Grappasonni et al. [4], Walker et al. [20], and Alpuguz et al. [21]. This questionnaire consisted of three different sections. Each section assesses different aspects of food related attitude and awareness. Knowledge of food poisoning and diseases transmitted through food, attitudes in dining areas, highrisk food groups, cross-contamination and awareness of incorrect food handling are evaluated within these sections.

The survey was proposed in the Turkish language to maritime students. To ensure that the instruments perform practically the same way as it does in English, a back-andforth translation has been carried out on the reference questionnaires. As the first step of this process, each author translated the questionnaire from English to the Turkish language. Each text was then separately translated back to English by third parties to assure validity. In the final step, two forms were compared with each other to eliminate any discrepancies. The final form included an introduction and consent section which explained the purpose of the research and listed the procedures of the survey for the participants.

The survey was conducted online using internet resources. Recruitment for the study was done with the help of student representatives and academic staff. These individuals distributed questionnaire link to those who were interested in joining the study. The questionnaire form was reviewed and approved by the related departments of universities before the distribution. Each participant was asked for consent before filling out the form and was reminded that they can reject to participate in the research. Therefore, the participation in the survey was on a voluntary basis. Only one response per participant was allowed. Data collection was carried out between 01.05.2018 and 21.05.2018. Two hundred fifty-one Turkish participants joined the study. All participants possessed a government-issued seafarer license (ranging from cadet to ocean going watch keeping officer/engineer) and were studying to get a bachelor's degree in maritime related areas. The carried-out study is a cross-sectional research and adopts convenience sampling technique. 


\section{STATISTICAL ANALYSIS}

Data collected from the participants were stored and processed in excel spreadsheets. SPSS (Statistical Package for the Social Sciences) 22.0 software was utilised for the statistical analysis. Main findings and results were obtained through the descriptive statistics and from chi-square analysis. Statistical significance was established at $p<0.05$.

\section{RESULTS}

Questionnaire answers of 251 maritime students were analysed in accordance with their classes and their undergraduate departments. Participants' answers were arranged by their years in education so that the $1^{\text {st }}$ and $2^{\text {nd }}$ graders (freshman and sophomore) and $3^{\text {rd }}$ and $4^{\text {th }}$ graders (junior and senior) represent two different groups. This grouping allowed a comparison between the experienced and inexperienced students. This was possible since maritime students in Turkey go through an open-sea training on merchant vessels before they advance to their $3^{\text {rd }}$ year. All participants were either studying Marine Transportation Engineering (MTE) or Marine Engineering (ME). Since these two departments also represent different departments on ships as deck and engine departments, a comparison between these groups was also made in this study. The sample group comprised mostly male students (84.9\%) which appear to be ordinary, considering the overall population of maritime students. The average age of the participants was 21.36. Demographic characteristics of the participants are shown in Table 1.

The first section in the survey investigated participants' food selection and consumption behaviours. Answers by the participants revealed food cost as the main influencer $(50.6 \%)$ in food selection of the individuals. $25.1 \%$ pointed out that they often settle for their families or friends' food choice. $18.7 \%$ of the participants did not think there were any major influencers in their food selection. Likewise, $48.2 \%$ of the participants noted that they do not discern between packaged or unpackaged foods. On the other hand, $41 \%$ indicated that they prefer packaged foods if there is any available. There weren't any observable significant differences in this section between class and department of students. Figures 1 and 2 show the distribution of these responses.

Table 2 shows the items that individuals pay attention (if available) before consuming food when they are on board. Answers revealed that majority of the participants (70.1\%) check the expiration date of the food as the first item. Nearly half of the participants (49\%) indicated that they pay attention to the brand of the food and $53.4 \%$ indicated that they check whether or not the package of the food is intact. On the contrary, only $16.3 \%$ stated that they inspect the storage conditions of the food. A worrisome finding showed that
Table 1. Demographic characteristics of participants

$\begin{array}{ll}\text { Department } & 175(69.7 \%) \\ \text { MTE } & 76(30.3 \%) \\ \text { ME } & 251(100 \%) \\ \text { Total } & \\ \text { Class } & 159(63.3 \%) \\ \text { Freshmen and sophomores } & 92(36.7 \%) \\ \text { Juniors and seniors } & 251(100 \%) \\ \text { Total } & \\ \text { Gender } & 38(15.1 \%) \\ \text { Female } & 213(84.9 \%) \\ \text { Male } & 251(100 \%) \\ \text { Total } & \\ \text { Age } & 18 \\ \text { Minimum } & 28 \\ \text { Maximum } & 21.36 \\ \text { Total } & \end{array}$

ME - Marine Engineering; MTE - Marine Transportation Engineering

$84.9 \%$ of the participants do not check if there is a food related organisation's approval on packages. Even though the attention towards storage conditions was low among all participant groups, it is observed that ME students were significantly less interested than the MTE students in checking the storage conditions of the foods on board $(p<0.05)$. Another significant difference between groups was on the consideration of the food's brand. Experienced students were significantly less interested in the brand of the food than the freshmen and sophomore students $(p<0.05)$. In a similar manner, ME students were paying significantly less attention to the brand of the food than the MTE students when they are on board $(p<0.05)$. Ingredients and nutritional values of the foods were also significantly less important for the experienced students than the other groups $(p<0.05)$.

Table 3 summarises the answers to the questions that were designed to assess knowledge of food poisoning, food hygiene, high-risk food groups, and cross-contamination. Answers revealed that nearly all participants (98\%) had knowledge that certain diseases can be transmitted through food. The overall knowledge of the students was rather limited on food handling and storing processes. Highest correct answer (64.9\%) was on the effect of refrigeration on pathogens. Another relatively high correct answer (64.5\%) was to the question of the symptoms of food poisoning. Most of the participants were unsuccessful to distinguish high-risk foods from relatively safe ones. Only $41.4 \%$ identified the favourable conditions for micro-organism multiplication in foods and only $21.5 \%$ recognised the cooked rice as a high- 


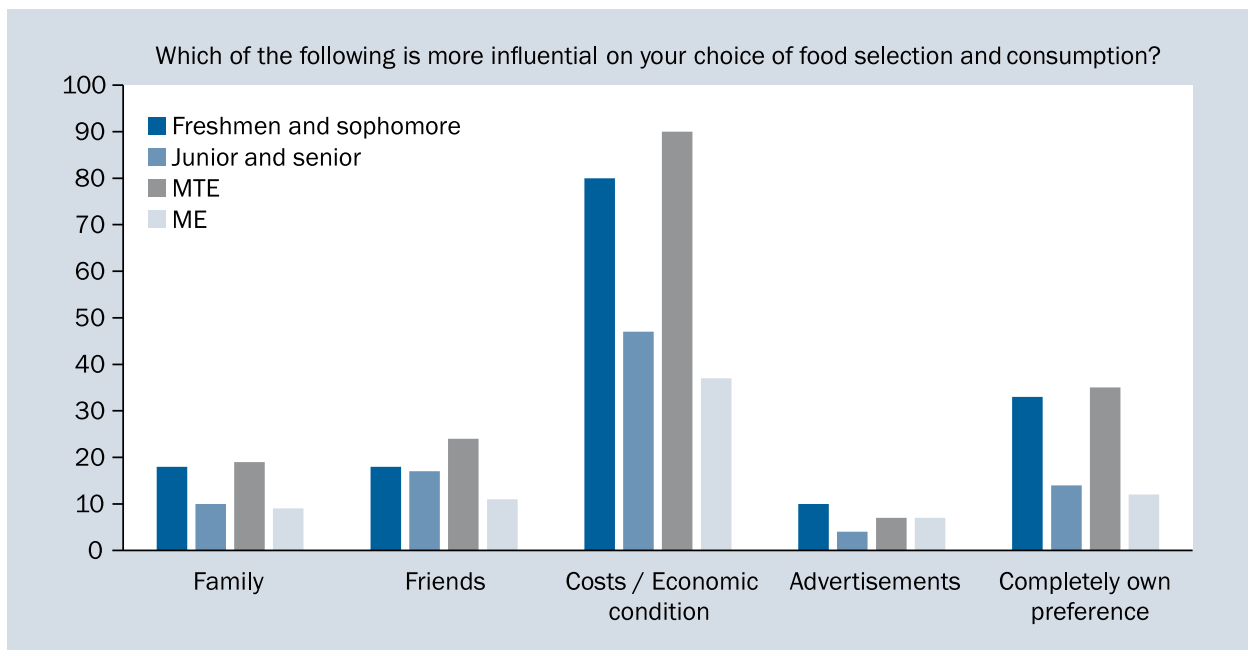

Figure 1. Main influencers in food selection; ME - Marine Engineering; MTE - Marine Transportation Engineering

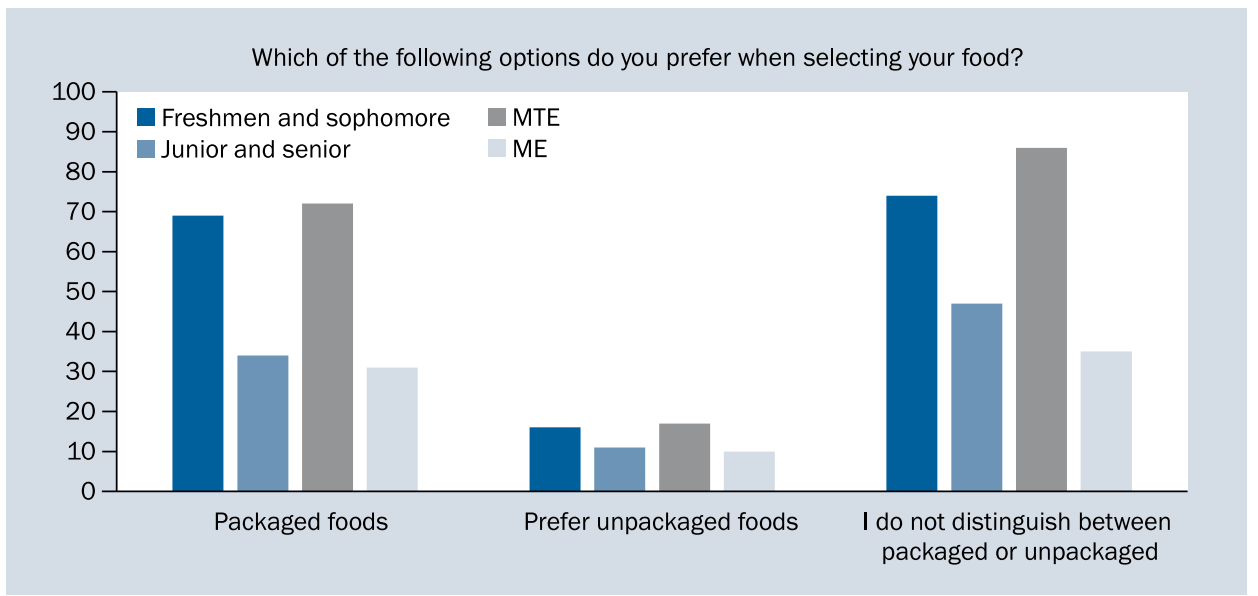

Figure 2. Packaged/unpackaged food preferences; ME - Marine Engineering; MTE - Marine Transportation Engineering

Table 2. Distribution of the points students pay attention to on packaged foods

\begin{tabular}{|c|c|c|c|c|c|}
\hline \multirow[t]{2}{*}{ Survey questions } & \multicolumn{2}{|l|}{ Class } & \multicolumn{2}{|c|}{ Department } & \multirow[t]{2}{*}{ Total } \\
\hline & $\begin{array}{l}\text { Freshmen } \\
\text { and sophomore }\end{array}$ & $\begin{array}{l}\text { Junior } \\
\text { and senior }\end{array}$ & MTE & ME & \\
\hline $\begin{array}{l}\text { What are the things you pay most attention } \\
\text { to in packaged foods? }\end{array}$ & Yes & Yes & Yes & Yes & \\
\hline Expiration date & $70.4 \%$ & $70.7 \%$ & $73.1 \%$ & $64.5 \%$ & $70.1 \%$ \\
\hline Whether the package is open or not & 54.1 & 52.2 & $56.0 \%$ & $47.4 \%$ & $53.4 \%$ \\
\hline Brand & $57.2 \% *$ & $35.9 \% *$ & $54.9 \% *$ & $36.8 \% *$ & $49 \%$ \\
\hline Ingredients & $40.3 \% *$ & $27.2 \%$ * & $38.3 \%$ & $28.9 \%$ & $35.5 \%$ \\
\hline Calorie value & $23.3 \%$ & $16.3 \%$ & $23.5 \%$ & $14.5 \%$ & $20.7 \%$ \\
\hline Nutritional values & $25.8 \% *$ & $10.9 \%$ * & $24.6 \%$ * & $10.5 \%$ * & $20.3 \%$ \\
\hline Storage conditions & $17.6 \%$ & $13.0 \%$ & $19.4 \% *$ & $7.9 \% *$ & $16.3 \%$ \\
\hline Related food organization's approval & $15.1 \%$ & $15.2 \%$ & $16.0 \%$ & $13.2 \%$ & $15.1 \%$ \\
\hline The place of production & $10.7 \%$ & $6.5 \%$ & $12.0 \%$ * & $2.6 \%$ * & $9.2 \%$ \\
\hline None of these & $1.3 \%$ & $1.1 \%$ & $1.1 \%$ & $1.3 \%$ & $3.6 \%$ \\
\hline
\end{tabular}

${ }^{*} \mathrm{p}<0.05$ significant differences between groups. ME - Marine Engineering; MTE - Marine Transportation Engineering 
Table 3. Answers to food safety related knowledge questions

\begin{tabular}{|c|c|c|c|}
\hline Questions & $\begin{array}{l}\text { Correct } \\
\text { answers }\end{array}$ & $\begin{array}{l}\text { Wrong } \\
\text { answers }\end{array}$ & $\begin{array}{l}\text { 'Do not } \\
\text { know' }\end{array}$ \\
\hline $\begin{array}{l}\text { Do you think that diseases can be transmitted through food? } \\
\left(y^{\star}{ }^{\star}, \text { no) }\right.\end{array}$ & $98 \%$ & $2 \%$ & - \\
\hline $\begin{array}{l}\text { Does refrigeration kill all the pathogens that may be present in food? } \\
\text { (no, but it preserves the food so that germs cannot multiply*; it just kills } \\
\text { the germs that are vulnerable to low temperatures; yes, it kills all the germs; } \\
\text { no, on the contrary, it facilitates their growth) }\end{array}$ & $64.9 \%$ & $27.1 \%$ & $8.0 \%$ \\
\hline $\begin{array}{l}\text { Which is a common symptom of food poisoning? } \\
\text { (headache, diarrhoea*, rash, constipation, do not know) }\end{array}$ & $64.5 \%$ & $27.1 \%$ & $8.4 \%$ \\
\hline $\begin{array}{l}\text { At body heat }\left(37^{\circ} \mathrm{C}\right) \text { what will food poisoning bacteria do? } \\
\text { (die, do not grow, grow quickly*, grow slowly) }\end{array}$ & $51.8 \%$ & $17.5 \%$ & $30.7 \%$ \\
\hline $\begin{array}{l}\text { Which foods are most favourable to micro-organism multiplication? } \\
\text { (those with the highest water content*, those with the lowest water content, very salty foods) }\end{array}$ & $41.4 \%$ & $30.3 \%$ & $28.3 \%$ \\
\hline $\begin{array}{l}\text { Is it appropriate to refreeze thawed food? } \\
\text { (not more than once, not more than } 3 \text { times, no never*, yes as many times as you'd like) }\end{array}$ & $25.5 \%$ & $56.2 \%$ & $18.3 \%$ \\
\hline $\begin{array}{l}\text { Hot food must be kept above which temperature? } \\
\left(22^{\circ} \mathrm{C}, 47^{\circ} \mathrm{C}, 63^{\circ} \mathrm{C}^{\star}, 77^{\circ} \mathrm{C}\right)\end{array}$ & $22.3 \%$ & $30.7 \%$ & $47.0 \%$ \\
\hline $\begin{array}{l}\text { Which of the following is most likely to cause food poisoning? } \\
\text { (prawn crackers, cooked rice*, plain naan bread, cheese and tomato pizza) }\end{array}$ & $21.5 \%$ & $78.5 \%$ & $0.0 \%$ \\
\hline $\begin{array}{l}\text { If food is contaminated with food poisoning bacteria, you can normally tell by? } \\
\text { (tasting, looking at, smelling, none of these*) }\end{array}$ & $3.2 \%$ & $85.6 \%$ & $11.2 \%$ \\
\hline
\end{tabular}

-risk food when presented with other options. In addition to that, most of the students struggled with proper storage procedures for frozen foods $(74.5 \%)$ and temperature control (78.5\%).

Table 4 lists the questions and answers for food hygiene awareness and knowledge. Participants were asked general questions related to food hygiene such as high-risk activities that favour germ development and food contamination. In response to these; $74.5 \%$ responded that leaving the food at room temperature for a long time will favour germ development. In the opinion of $59.8 \%$ putting cooked food in contact with raw food did not lead to germ development. Personal and environmental hygiene was determined to be the main concern in all groups. Hence, hands handling the food $(71.3 \%)$, personal hygiene $(65.7 \%)$ and environmental hygiene (57.4\%) were the most common answers. A significant difference between the MTE and ME students was observed regarding environmental hygiene. ME students thought the hygiene of the surroundings were less of a concern in food contamination $(p<0.05)$. Other significant differences were on the prevention of food contamination. ME students, as well as novice students, significantly favoured the effectiveness of freezing and cooking foods to avoid contamination ( $p<0.05)$.

In addition to these questions, participants were asked to assess the main risk factors on merchant vessels regarding the foodborne diseases. It is revealed that $63.3 \%$ perceive the improper storage temperature of the foods as the main risk factor for disease transmission on board. Oddly enough, participants did not consider cross-contamination as a high-risk factor. Only $32.7 \%$ and $36.7 \%$, respectively, believed the contamination of cooked food with raw food and contaminated utensils may create a disease risk. This ratio was significantly lower in ME students when it is compared with MTE students ( $p<0.05)$. Instead, $48.2 \%$ of the participants considered poor hygiene of the food handler a greater risk. However, only $32.7 \%$ thought catering personnel carrying pathogens could factor a high-risk of disease transmission. Poor hygiene conditions of food handler were observed to be more concerning both for the MTE department and inexperienced students compared to ME department and experienced students $(p<0.05)$.

\section{DISCUSSION}

This study shows that the most important factor in food choice was the costs of the food and the economic status of the individual. Similar results were obtained in various studies regarding the food selection [8, 9]. However, a study conducted by Alpuguz et al. [21] found that these criteria (cost/economic condition) were the least important factors among the undergraduate students which contradict with our findings. The same study determined that the individual's own preferences were the most influencing factor in food choice. Own preference response is lower in our study compared to these findings. Regarding food selection, most of the participants indicated that they prefer packaged 
Table 4. Distribution of food safety awareness and knowledge answers

\begin{tabular}{|c|c|c|c|c|c|}
\hline \multirow[t]{3}{*}{ Survey questions } & \multicolumn{2}{|l|}{ Class } & \multicolumn{2}{|c|}{ Department } & \multirow[t]{3}{*}{ Total } \\
\hline & \multirow{2}{*}{$\begin{array}{l}\begin{array}{l}\text { Freshmen } \\
\text { and sophomore }\end{array} \\
\text { Yes }\end{array}$} & \multirow{2}{*}{$\begin{array}{l}\text { Junior } \\
\text { and senior } \\
\text { Yes }\end{array}$} & \multirow{2}{*}{$\begin{array}{l}\text { MTE } \\
\text { Yes }\end{array}$} & ME & \\
\hline & & & & Yes & \\
\hline \multicolumn{6}{|c|}{ In your opinion, which of the following activities favour the development of germs in food? } \\
\hline Leaving the food at room temperature for a long time & $78.6 \%$ & $67.4 \%$ & $78.3 \%$ * & $65.8 \% *$ & $74.5 \%$ \\
\hline Putting cooked food in contact with raw food & $43.4 \%$ & $34.8 \%$ & $41.1 \%$ & $38.2 \%$ & $40.2 \%$ \\
\hline Reheating food at high temperatures & $22.0 \%$ & $20.7 \%$ & $21.7 \%$ & $21.1 \%$ & $21.5 \%$ \\
\hline Refrigerating food in large pots & $20.8 \%$ & $20.7 \%$ & $19.4 \%$ & $23.7 \%$ & $20.7 \%$ \\
\hline Consuming food immediately after cooking it & $11.3 \%$ & $9.8 \%$ & $10.3 \%$ & $11.8 \%$ & $11.2 \%$ \\
\hline \multicolumn{6}{|l|}{ Food get contaminated with microorganisms mainly through } \\
\hline Hands handling food & $75.5 \%$ & $64.1 \%$ & $73.1 \%$ & $67.1 \%$ & $71.3 \%$ \\
\hline Food containers & $56.6 \%$ & $51.1 \%$ & $57.1 \%$ & $48.7 \%$ & $54.6 \%$ \\
\hline Air & $57.2 \%$ & $44.6 \%$ & $56.0 \%$ & $44.7 \%$ & $52.6 \%$ \\
\hline \multicolumn{6}{|l|}{ How can food contamination be avoided? } \\
\hline Personal hygiene & $69.2 \%$ & $59.8 \%$ & $68.6 \%$ & $59.2 \%$ & $65.7 \%$ \\
\hline Environmental hygiene & $59.7 \%$ & $53.3 \%$ & $62.9 \%$ * & $44.7 \% *$ & $57.4 \%$ \\
\hline Separating cooked from uncooked foods & $56.6 \% *$ & $40.2 \% *$ & $52.6 \%$ & $46.1 \%$ & $50.6 \%$ \\
\hline Separating meat from vegetables & $44.0 \%$ & $34.8 \%$ & $47.4 \% *$ & $25.0 \% *$ & $40.6 \%$ \\
\hline Refrigeration & $48.4 \% *$ & $30.4 \% *$ & $47.4 \% *$ & $28.9 \% *$ & $41.8 \%$ \\
\hline Freezing & $47.2 \% *$ & $26.1 \% *$ & $45.7 \%$ * & $25.0 \% *$ & $39.4 \%$ \\
\hline Cooking & $41.5 \%$ & $29.3 \%$ & $40.6 \%$ & $28.9 \%$ & $37.1 \%$ \\
\hline \multicolumn{6}{|c|}{ In your opinion, what are the main risk factors for disease transmission through food on board? } \\
\hline Improper storage temperature & $64.8 \%$ & $60.9 \%$ & $65.1 \%$ & $59.2 \%$ & $63.3 \%$ \\
\hline Poor hygiene of the person preparing/distributing food & $54.1 \% *$ & $38.0 \% *$ & $53.7 \% *$ & $35.5 \% *$ & $48.2 \%$ \\
\hline Improper cooking process; & $46.5 \%$ & $45.7 \%$ & $45.1 \%$ & $48.7 \%$ & $46.2 \%$ \\
\hline Uncertain origin of food & $37.1 \%$ & $34.8 \%$ & $38.3 \%$ & $31.6 \%$ & $35.1 \%$ \\
\hline Excessive time between the preparation and consumption of food & $42.8 \% *$ & $28.3 \% *$ & $40.0 \%$ & $31.6 \%$ & $37.5 \%$ \\
\hline Contaminated utensils & $40.3 \%$ & $29.3 \%$ & $41.7 \% *$ & $23.7 \% *$ & $36.7 \%$ \\
\hline Contamination of cooked food by raw food & $36.5 \%$ & $25.0 \%$ & $35.4 \%$ & $25.0 \%$ & $32.7 \%$ \\
\hline Pathogen-carrying catering personnel & $35.8 \%$ & $26.1 \%$ & $34.9 \%$ & $26.3 \%$ & $32.7 \%$ \\
\hline
\end{tabular}

${ }^{*} \mathrm{p}<0.05$ significant differences between groups. ME - Marine Engineering; MTE - Marine Transportation Engineering

foods. This finding is in line with the findings of Alpuguz et al. [21]. It should also be noted that elements individuals pay attention in food selection differ a lot. In the works of McArthur et al. [10] condition of the food package had a high rate of answer, yet in our study package condition observed to be less of a concern. We also found that some individuals do not distinguish packaged and unpackaged foods when selecting. Instead, it is revealed that undergraduate maritime students pay a great attention to the expiration date and package conditions of foods. This result is consistent and in line with other studies in the literature. Since our findings on food selection criteria seem to be both alike and different with several studies, it should be considered that there could be unsought factors (age, nationality, etc.) affecting the food selection of individuals. So these findings should be interpreted as circumstantial.

Most of our participants have knowledge that diseases can be transmitted through food. The correct response rate for this question is higher in this study than the study of Grappasonni et al. [4] where the correct answers rate was $76.5 \%$. The rate of knowledge on the symptoms of foodborne diseases is very similar to findings of Low et al. [12]. However, this does not mean that seafarers possess the knowledge of foodborne diseases. In fact, Türkistanli and Sevgili [22] found that most of the seafarers were indeed aware of the foodborne diseases yet they often failed to 
identify the characteristics and symptoms of these diseases. Probably the most worrisome finding is that participant's inability to tell the correct way to identify contaminated food. Most of them believed it is possible to tell if a food is contaminated by smelling it. However, it is not possible to tell whether a food is contaminated with for example $E$. coli. These findings on foodborne diseases are also supported with the fact of participant's incapability to identify high-risk foods. Such as, individuals lack knowledge that high-water content foods, such as cooked rice, are favourable to micro-organism multiplication. Similarly, participants lacked knowledge on the temperature control of the foods. It is also proved by other studies that temperature control and high-risk food groups are more known by food handlers $[4,20]$. This should be accepted as reasonable since these students won't take roles as food handlers on board. Even so, knowledge about the high-risk food groups should be common knowledge for all individuals.

There are also few noteworthy findings on the knowledge of food storage processes. Correct answer rate for the effects of refrigeration process on pathogens is slightly higher in our study than the observed rates in the study of Grappasonni et al. [4]. On the contrary, seafarers and ashore personnel in the study of Grappasonni et al. [4] had higher correct answers for the micro-organism multiplication and thawed food questions. These findings compared; it can be said that our participants' knowledge of food storing conditions is below average.

Regarding the risky behaviours on board considering food hygiene, our findings show that maritime students have knowledge and awareness deficiencies. For instance, most students know that leaving foods at room temperature for a long time is a risky behaviour but most of them failed to notice that hot food refrigerated in large pots may possess a similar risk. It is determined that most of our participants were concerned with personal hygiene and environmental hygiene in food contamination. In addition, they believe the food handler's hygiene is more important than food storage and preparation process. A notable finding shows that our participants mostly ignore other factors that might result in food contamination, such as cross-contamination. Diseases like Salmonellosis are mostly transmitted from raw foods to cooked foods. So cross-contamination and food preparation are as much important as the hygiene of the food handler.

In general, foodborne outbreaks on board ships are caused by inadequate food temperature control, infected food handlers, contaminated raw ingredients and cross-contamination [6]. Even though the digestive and gastroenteral diseases constitute a small percentage of the causes of death among seafarers, it is important to keep these diseases under control to improve overall well-being of seafarers
$[23,24]$. For this reason, training in food hygiene during the education process of maritime students can be very beneficial which is also proposed by several other studies [10, 12, 15-17, 19].

\section{CONCLUSIONS}

Food hygiene appears to be an underrated problem on board, yet it is one of the major problems in the maritime industry threatening the health of seafarers. Food hygiene-related problems affect seafarers' health and overall well-being. Ways to treat food-related diseases are limited while the ship is underway without medical professionals on board. It is important to create an environment that favours avoidance and prevention from such diseases. Promoting food safety culture with food hygiene knowledge and awareness in maritime students could be a key factor towards this goal. We must aim to eliminate risky behaviours regarding food hygiene on board. This study highlights the shortcomings of maritime students regarding food safety. Further studies should consider examining maritime companies' rules and attitudes toward food hygiene on board. We believe the way to eliminate the food contaminations on merchant vessels can be achieved by training the whole crew. Development of standardised health and disease training for seafarers should also be considered.

\section{REFERENCES}

1. Grappasonni I, Petrelli F, Scuri S, et al. Knowledge and Attitudes on Food Hygiene among Food Services Staff on Board Ships. Ann Ig. 2018; 30(2): 162-172, doi: 10.7416/ai.2018.2207, indexed in Pubmed: 29465153.

2. Rooney RM, Cramer EH, Mantha S, et al. A review of outbreaks of foodborne disease associated with passenger ships: evidence for risk management. Public Health Rep. 2004; 119(4): 427-434, doi: 10.1016/j.phr.2004.05.007, indexed in Pubmed: 15219800.

3. Schlaich CC, Oldenburg M, Lamshöft MM. Estimating the risk of communicable diseases aboard cargo ships. J Travel Med. 2009; 16(6): 402-406, doi: 10.1111/j.1708-8305.2009.00343.x, indexed in Pubmed: 19930380.

4. Grappasonni I, Marconi D, Mazzucchi F, et al. Survey on food hygiene knowledge on board ships. Int Marit Health. 2013; 64(3): 160-167, indexed in Pubmed: 24072544.

5. Koo D, Maloney K, Tauxe R. Epidemiology of diarrheal disease outbreaks on cruise ships, 1986 through 1993. JAMA. 1996; 275(7): 545-547, doi: 10.1001/jama.1996.03530310051032, indexed in Pubmed: 8606476.

6. Mouchtouri VA, Westacott S, Nichols G, et al. Hygiene inspections on passenger ships in Europe - an overview. BMC Public Health. 2010; 10: 122, doi: 10.1186/1471-2458-10-122, indexed in Pubmed: 20219097.

7. Mouchtouri V, Malissiova E, Zisis P, et al. Assessment of hygiene standards and Hazard Analysis Critical Control Points implementation on passenger ships. Int J Environ Health Res. 2013; 23(2): 170-179, doi: 10.1080/09603123.2012.708920, indexed in Pubmed: 22852776.

8. Purutcuoglu E, Bayraktar M. Investigating the need for consumer education among Turkish secondary school students. Int J Con- 
sumer Studies. 2004; 28(5): 443-453, doi: 10.1111/j.14706431.2004.00403.x.

9. Yaman M, Özgen L. Üniversite öğrencilerinin yurtlarındaki besin Hijyeni yaklaşımları ve besin hazırlama uygulamaları. Gazi Üniversitesi Endüstriyel Sanatlar Eğitim Fakültesi Dergisi. 2007; 20: 28-38.

10. McArthur LH, Holbert D, Forsythe WA. College students and awareness of food safety. J Family Consumer Sciences. 2007; 99(1): 60.

11. Avarand A, Abedi SA. Analysis of knowledge and attitude towards food safety among university students in Gorgan city. J Food Hygiene. 2015; 5(17): 53-66.

12. Low W, Jani R, Halim H, et al. Determinants of food hygiene knowledge among youths: A cross-sectional online study. Food Control. 2016; 59: 88-93, doi: 10.1016/j.foodcont.2015.04.032.

13. Almansour M, Sami W, Al-Rashedy OS, et al. Knowledge, attitude, and practice (KAP) of food hygiene among schools students' in Majmaah city, Saudi Arabia. J Pak Med Assoc. 2016; 66(4): 442-446, indexed in Pubmed: 27122273.

14. Courtney SM, Majowicz SE, Dubin JA. Food safety knowledge of undergraduate students at a Canadian university: results of an online survey. BMC Public Health. 2016; 16(1): 1147, doi: 10.1186/ s12889-016-3818-y, indexed in Pubmed: 27829398.

15. Garayoa R, Cordoba M, Garcia-Jalon I, et al. Relationship between consumer food safety knowledge and reported behavior among students from health sciences in one region of Spain. J Food Protection. 2005; 68(12): 2631-2636, doi: 10.4315/0362-028x-68.12.2631.

16. Giritlioglu I, Batman 0, Tetik N. The knowledge and practice of food safety and hygiene of cookery students in Turkey. Food Control. 2011; 22(6): 838-842, doi: 10.1016/j.foodcont.2010.09.016.
17. Sanlier N, Bilici S, Çelik B, et al. Food safety knowledge and practices of nursing students. Italian J Food Science. 2012; 24(1): 86-93.

18. Şimşek A. Hijyen alışkanlıklarını belirlemeye yönelik bir araştırma: Atatürk Üniversitesi Turizm Fakültesi örneği. Ordu Üniversitesi Sosyal Bilimler Araştırmaları Dergisi. 2017; 7(2): 149-156.

19. Stratev D, Odeyemi OA, Pavlov A, et al. Food safety knowledge and hygiene practices among veterinary medicine students at Trakia University, Bulgaria. J Infect Public Health. 2017; 10(6): 778-782, doi: 10.1016/j.jiph.2016.12.001, indexed in Pubmed: 2818811.

20. Walker E, Pritchard C, Forsythe S. Food handlers' hygiene knowledge in small food businesses. Food Control. 2003; 14(5): 339-343, doi: 10.1016/s0956-7135(02)00101-9.

21. Alpuğuz G, Erkoç F, Mutluer B, et al. Gençlerin (14-24 yaş) gıda hijyeni ve ambalajlı gıdaların tüketimi konusundaki bilgi ve davranışlarının incelenmesi. Türk Hijyen ve Deneysel Biyoloji Dergisi. 2009; 66(3): 107-115.

22. Türkistanlı TT, Sevgili C. Awareness of health risks and communicable diseases among undergraduate maritime students. Int Marit Health. 2018; 69(2): 142-148, doi: 10.5603/IMH.2018.0021, indexed in Pubmed: 29939392.

23. Grappasonni I, Petrelli F, Amenta F. Deaths on board ships assisted by the Centro Internazionale Radio Medico in the last 25 years. Travel Med Infect Dis. 2012; 10(4): 186-191, doi: 10.1016/j. tmaid.2012.06.006, indexed in Pubmed: 22819258.

24. Grappasonni I, Paci P, Mazzucchi F, et al. Awareness of health risks at the workplace and of risks of contracting communicable diseases including those related to food hygiene, among seafarers. Int Marit Health. 2012; 63(1): 24-31. 